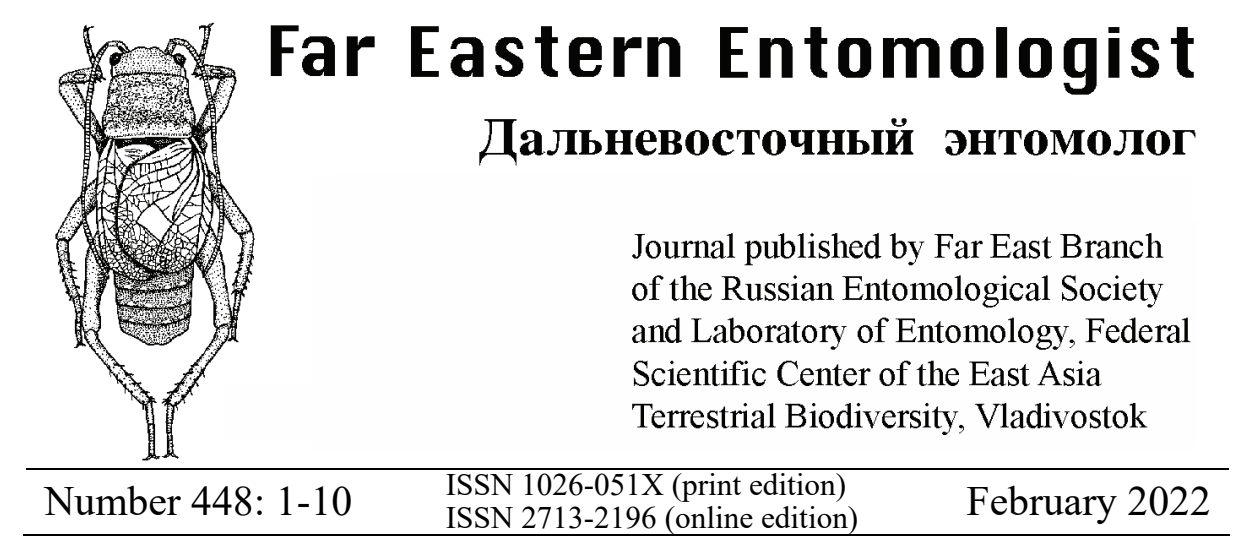

https://doi.org/10.25221/fee.448.1

http://zoobank.org/References/AEDC82ED-B0CD-4998-9EDD-FBB5CF1D1B4D

\title{
NEW RECORDS OF THE SKIN BEETLES (COLEOPTERA: DERMESTIDAE) FROM RUSSIA, CENTRAL ASIA AND IRAN, WITH DESCRIPTION OF A NEW SPECIES FROM KAZAKHSTAN
}

\section{E. A. Khachikov ${ }^{1)}$,J. Háva ${ }^{2)}$, S. V. Poushkova ${ }^{3)}$}

1) Academy of Biology and Biotechnology, Southern Federal University, Stachki Str., 194/1, Rostov-on-Don, 344090,_Russia.E-mail:e_hachikov@mail.ru

2) Forestry and Game Management Research Institute, Strnady 136, CZ-252 02 Praha 5 - Zbraslav, Czech Republic.E-mail: jh.dermestidae@volny.cz

3) Southern Scientific Centre of the Russian Academy of Sciences, Chekhov Str., 41, Rostov-on-Don, 344006, Russia.E-mail:posvet0578@gmail.com

Summary. Phradonoma beskalensis sp. n. is described from Kazakhstan. New species is similar to $P$. villosulum but differs from latter in the shape of antennae and in the structure of male genitalia. Thorictus koenigi Reitter, 1887 is recorded from Turkmenistan for the first time, Phradonoma villosulum (Duftschmid, 1825) is new for the fauna of Uzbekistan, Ph. nigrum Háva, 2006 is recorded for the first time from Iran, and two species, Attagenus cyphonoides (Reitter, 1881) and Dermestes erichsoni Ganglbauer, 1904, are new for the Rostov region of Russia.

Key words: skin beetles, Coleoptera, Dermestidae, taxonomy, new species, fauna, new records, Palaearctic region.

Э. А. Хачиков, Дж. Хава, С. В. Поушкова. Новые находки жуковкожеедов (Coleoptera: Dermestidae) в России, Центральной Азии, Иране и на Кавказе с описанием нового вида из Казахстана // Дальневосточный энтомолог. 2022. N 448. C. 1-10. 
Резюме. Из Казахстана описан Phradonoma beskalensis sp. n. Новый вид близок к P. villosulum, но отличается от него формой усиков и гениталий самца. Впервые для Туркменистана приводится Thorictus koenigi Reitter, 1887, для Узбекистана - Phradonoma villosulum (Duftschmid, 1825, для Ирана - Ph. nigrum Háva, 2006, a Attagenus cyphonoides (Reitter, 1881) и Dermestes erichsoni Ganglbauer, 1904 впервые указываются для Ростовской области России.

\section{INTRODUCTION}

There are a lot of data on the skin beetles (Coleoptera: Dermestidae) from southern regions of European part of Russia and adjacent countries (Zhantiev, 1976; Pushkin, 2002; Háva, 2006; Khachikov, 2008; Zhantiev, 2011) summarized by Háva (2015). This paper presents new records of Dermestidae from Europe and Asia. We also find and describe a new species of the genus Phradonoma Jacquelin $\mathrm{du}$ Val, 1859 in Kazakhstan. The economic significance of the species is also briefly discussed.

\section{MATERIAL AND METHODS}

Present paper is based on materials from the collections of the Department of Zoology of the Academy of Biology and Biotechnology named after D.I. Ivanovsky SFU, Rostov-on-Don (CZ), the Zoological Institute of the Russian Academy of Sciences, St. Petersburg (ZIN), and the Zoological Museum of Moscow State University, Moscow (ZMMU).

The specimens studied here were mounted onto cardboards or plastic plates with water-soluble glue. Genital preparations of both sexes are placed in a container with glycerol or in varnish on a transparent plastic plate and pinned to the corresponding specimens. For the species of the genus Phradonoma separate preparations of genitals and antennae were made in Hoyer's medium. For some species, detailed illustrations of their morphological structures are given due to the difficult identification. The preparations were examined using an Olympus BX41 microscope and an Olympus SZ 61 stereo-microscope.

The nomenclature of Dermestidae follows the catalogue by Háva (2015).

\section{RESULTS}

\section{Genus Phradonoma Jacquelin du Val, 1859}

Phradonoma villosulum (Duftschmid, 1825)

Figs 1-3, 9, 10, 13-18, 21

MATERIAL EXAMINED. Russia: Saratov region: Krasnokutskii distr., Dyakovka vill. env., 25-28.VI 2012, 20, leg. D. Astakhov (ZIN); Volgograd region: Sarepta [=now part of Volgograd], 1ㅇ, leg. Bekker (ZIN); Rostov region: Sholokhovskii distr., Veshenskaya vill., 10.VII 2001, 1, leg. E. Khachikov (CZ); 
Tsimlyanskii distr., reserve "Tsimlyansky", sector 7, 47 $55^{\prime} 59^{\prime \prime} \mathrm{N}, 42^{\circ} 13^{\prime} 11^{\prime \prime} \mathrm{E}, 21-$ 25.VI 2019, 14ð̄, 15, leg. E. Khachikov \& S. Poushkova (CZ); Ust-Donetskii distr., Nizhne-Kundruchenskaya vill., 9-11.V 2019, 4ð̊, 19, leg. E. Khachikov (CZ); Crimea: Yevpatoria, 18.VII 1905, 1 ㅇ, leg. V.V. Yakovlev (ZIN); Theodosia,
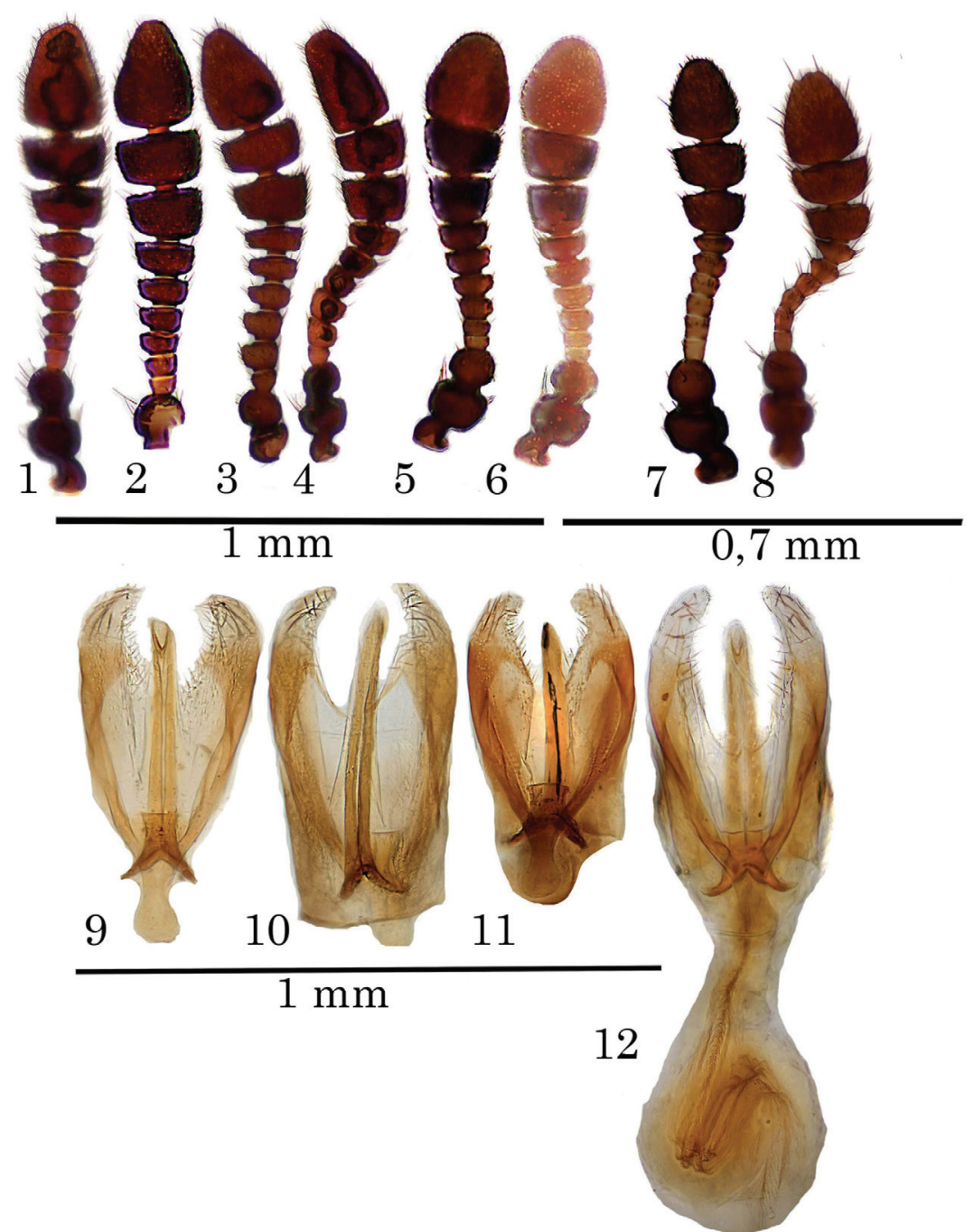

Figs 1-12. Antennae and male genitalia of Phradonoma spp. 1-3, 7, 9, $10-P h$. villosulum: 1- antennae of male from Austria; 2 - the same, Rostov region, 3 - the same, Uzbekistan; 7 antennae of female; 9 - male genitalia, ventrally; 10 - the same, dorsally; $104,12-P h$. parthicum: 4 - antennae of male; 12 - male genitalia; 5, 6, $11-P h$. beskalensis $\mathbf{s p .}$ n.: 5 antennae of male; 6 - the same, phase-contrast; 11 - male genitalia; 8 -Ph. nigrum, antennae of female. 
Dvuyakornaya Bay, 1.VII 1902, $1 \lesssim$ (ZMMU); Uzbekistan: Aman-Kutan, S of Samarkand, 4.VII 1932, 1§, leg. Gussakovskii (labelled as Phradonoma parthicum Zhant., Zhantiev det.) (ZIN); Germany: 3q, (M. Mroczkowski det., 1958) (ZIN); Austria: Kraatz, 1ð, 1, (M. Mroczkowski det., 1958) (ZIN).

DISTRIBUTION. Europe, Russia (European part, Caucasus), Turkey, Syria, Iran, Kyrgyzstan (Pushkin, 2002, 2019; Háva, 2006, 2015; Khachikov, 2008). New record for Uzbekistan.

REMARKS. Specimens recorded from Rostov region (Rostov-on-Don and Nedvigovka) by Pushkin (2019) are absent in the collection of the Department of Zoology of the Academy of Biology and Biotechnology (CZ).

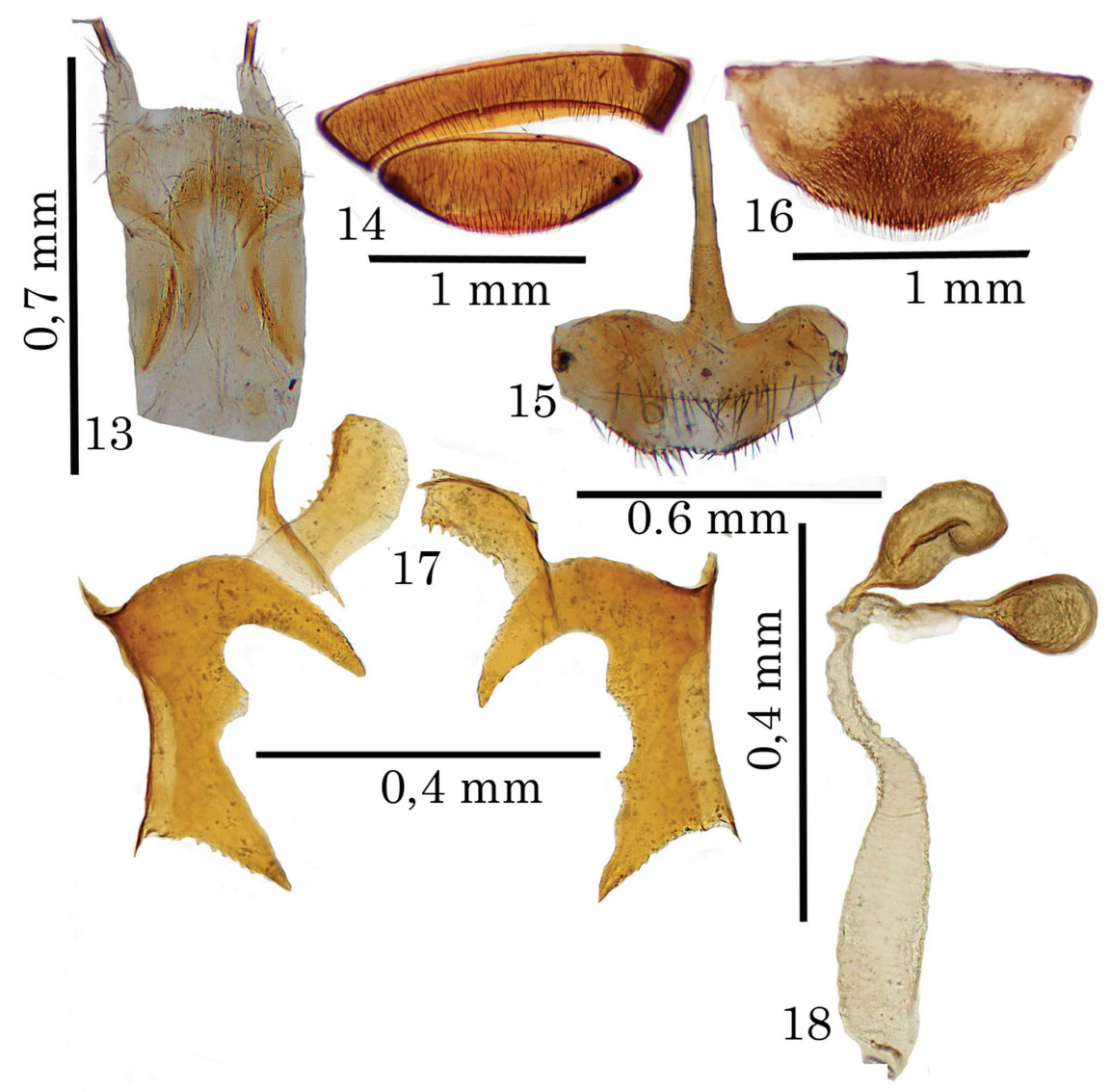

Figs 13-18. Phradonoma villosulum, +. 13 - IX genital segment; 14 - VII-VIII sternites; 15 - IX sternite; 16 - VIII tergite; 17 - sclerites in bursa copulatrix; 18 - spermatheca. 
Phradonoma parthicum Zhantiev, 1976

Figs 4, 12

MATERIAL EXAMINED. Uzbekistan: Aman-Kutan, S of Samarkand, 4.VII 1932, $1 \overbrace{}^{\lambda}$, leg. Gussakovskii (ZIN).

DISTRIBUTION. Kazakhstan, Uzbekistan, Turkmenistan (Zhantiev, 1976; Háva, 2015).

Phradonoma nigrum Háva, 2006

Fig 8

MATERIAL EXAMINED. Iran: Kerman, Bampur, 21-22.IV 1901, 2 , leg. N. Zarudnyi (ZIN); Tavriz [=Tebriz], Bagishemal, 9.VII 1914, 1ㅇ, leg. Andreevskii (ZIN). All specimens labelled as P. hirsutulum (Reiche in Mulsant et Rey, 1868), M. Mroczkowski det., 1958.

DISTRIBUTION. Turkey (Háva, 2015). New record for Iran.

Phradonoma beskalensis Khachikov, Háva et Poushkova, sp. n.

http://zoobank.org/NomenclaturalActs/5EC87AAA-82E9-4F8A-8FA1-2B92E35CCC9B

Figs 5, 6, 11, 19, 20

TYPE MATERIAL. Holotype - $\hat{\delta}$, Kazakhstan: Guryev Region [= Atyrau Region], Kois tract, Beskala vill. [=Madeniet vill.], 05.VII 1980, leg. E.A. Khachikov (ZIN).

DESCRIPTION. Body length is $2.1 \mathrm{~mm}$, the top is dark, almost matte, covered with erect reddish setae. Head is transverse, with coarse and rare punctation, with long more or less decumbent yellow-brown setae, maxillary palpi darkish brown, eyes large with microsetae. Forehead with ocellus. Antennae 11-segmented with a 5-antennomered club (Figs 5, 6), 11th-9th antennomeres larger than 8th and 7th; the 11th antennomere is apically smoothly narrowed and rounded; 10th antennomere transverse, slightly widened apically and basally rounded; the 9th antennomere (main segment of the club) is transverse, in the form of inverted parallelepiped; the 5th to 8th antennomeres are strongly transverse, slightly rounded; the 1st and 2nd antennomeres are slightly transverse and apically widened. The first antennomere is brown, the club very darkish brown and all other segments are light brown. Pronotum is entirely dark brown, shiny, sparsely and not very coarsely punctate, with yellowbrown setae (Fig. 19), apically smoothly narrowed, almost as wide as elytra. Basal margin of pronotum is in the form of an obtuse angle, the apex of which is at its middle. The scutellum is small, dark brown, triangular, without setation or punctures. Elytra dark brown anteriorly, light brown posteriorly, coarsely and sparsely punctate, sparsely covered by yellow-brown setae. Elytra are also gradually tapering towards the posterior margin of the body, and more than 2.5 times as long as the pronotum. The underside of the specimen is finely and more densely punctate than the elytra. Tibiae and tarsi are brown, the femurs darkened. Male genitalia as in Fig. 11. 
DIAGNOSIS. The new species is similar to Phradonoma villosulum but reliably different in the shape of the antennomeres. In P. villosulum the 9th and 10th antennomeres are much more transverse and widened, while the 8th-6th antennomeres are contrastingly narrower than in $P$. beskalensis $\mathrm{sp}$. $\mathrm{n}$. There are also differences in the structure of the male genitalia, especially in parameres (Fig. 11), which are wider in the distal part. P. beskalensis also differs from other species of the "villosulum" group of the genus Phradonoma in the structure of antennomeres and male genitalia (Háva, 2006).

DISTRIBUTION. Kazakhstan.

ETYMOLOGY. A name of new species derived from Beskala village, the environs of which being the type locality of this species.

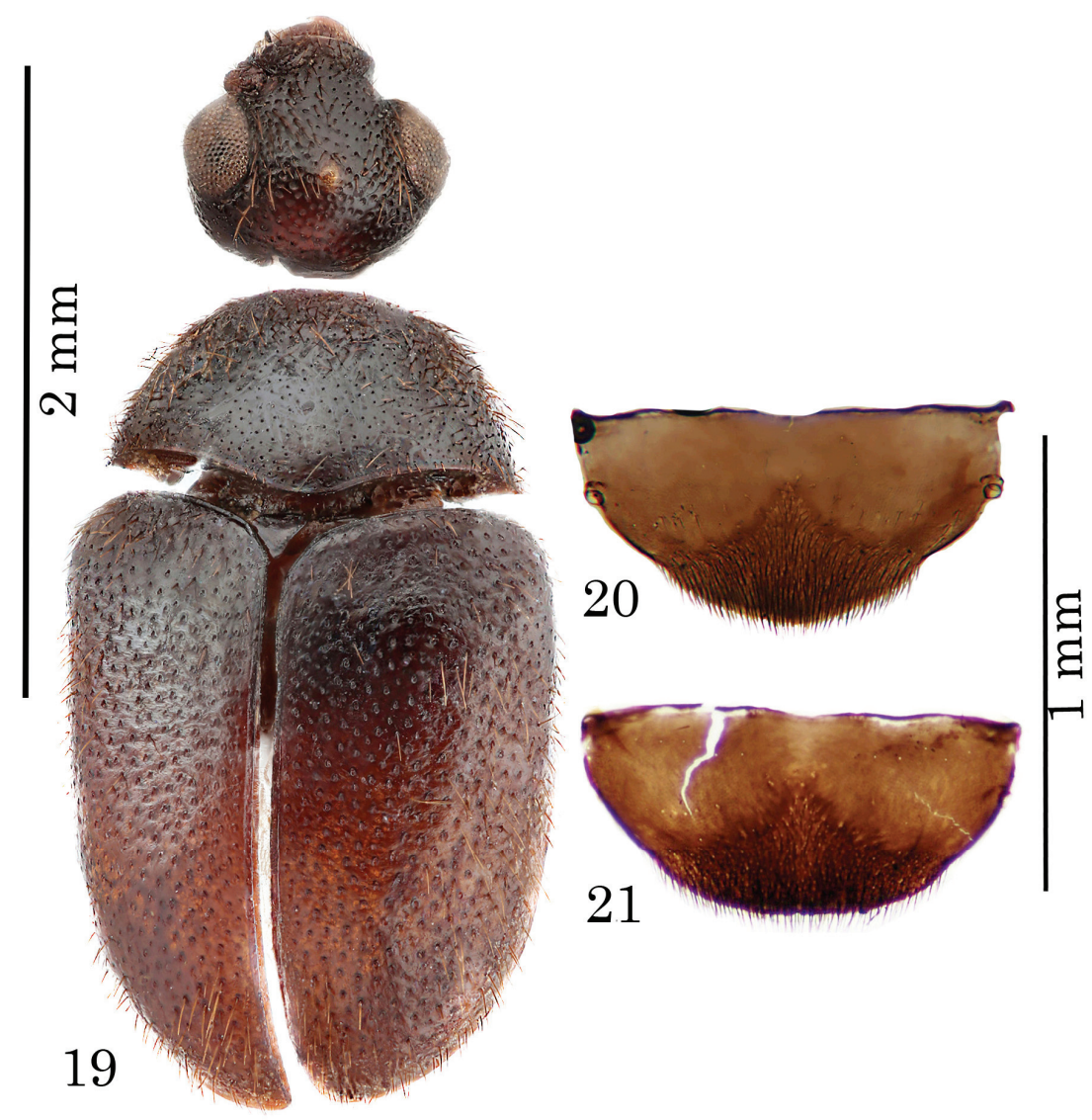

Figs 19-21. Phradonoma spp. 19, 20 - Ph. beskalensis sp. n.: 19 - dorsal aspect of body; 20 - VIII tergite; 21 - Phradonoma villosulum, VIII tergite. 


\section{Genus Attagenus Latreille, 1802}

Attagenus cyphonoides (Reitter, 1881)

Figs 22-28

MATERIAL EXAMINED. Russia: Rostov region: Rostov-on-Don, 7-9.VII 2020, 6今̂, 2ᄋ, leg. E. Khachikov (CZ).

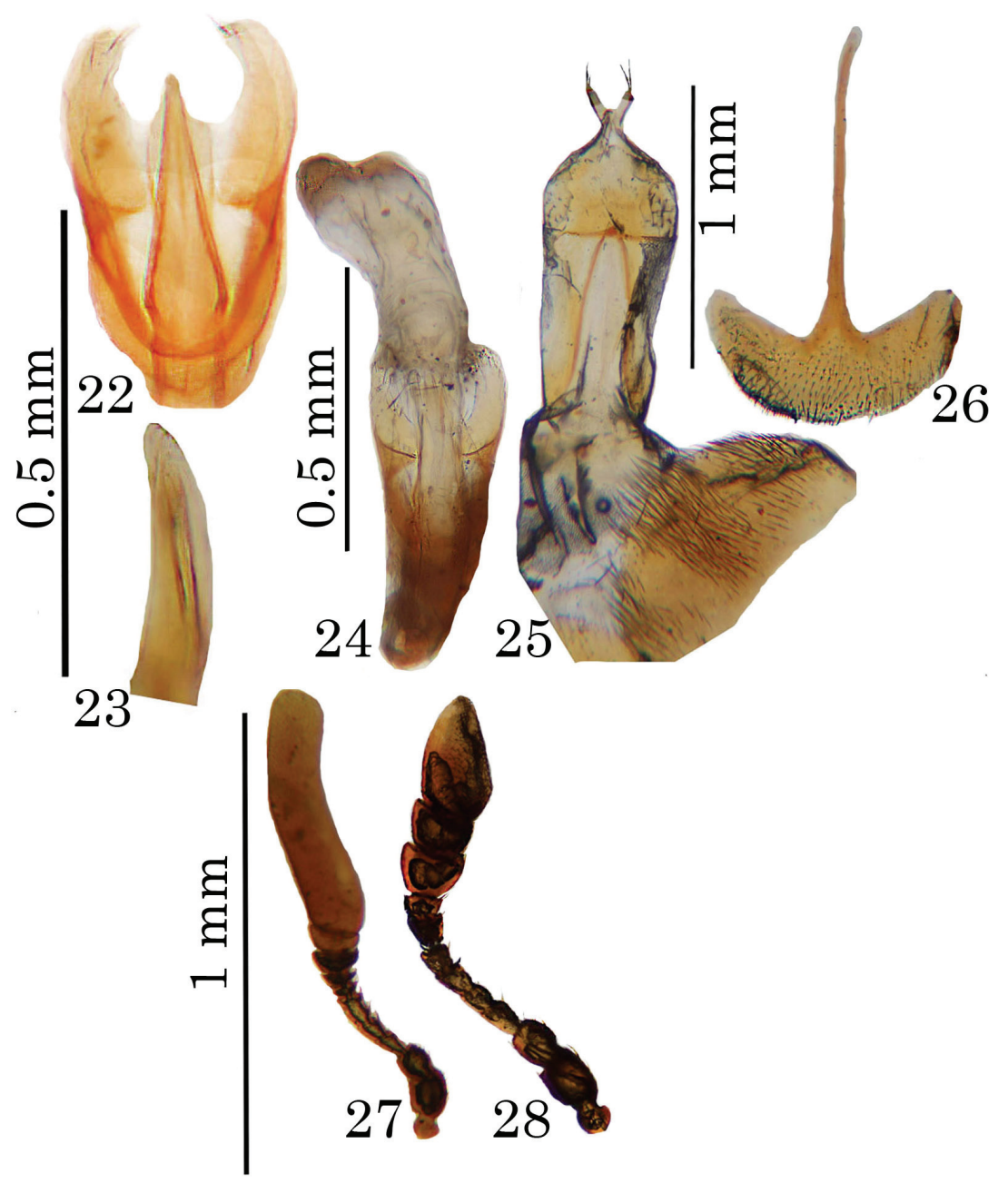

Figs 22-28. Attagenus cyphonoides: 22 - male genitalia; 23 - median lobe, lateral aspect; 24 - endophallus. 25 - female genitalia; 26 - IX sternite. 27 - antennae of male, 28 - antennae of female. 
DISTRIBUTION. Holarctic Region, Pakistan, India, Mexico, Australia (Háva, 2015). New record for Rostov region.

REMARKS. Attagenus cyphonoides is known as a pest of the furs, museum collections and grain (Zhantiev, 1976; Peacock, 1993).

\section{Genus Thylodrias Motschulsky, 1839}

\section{Thylodrias contractus Motschulsky, 1839}

MATERIAL EXAMINED. Russia: the Republic of Kalmykia: Elista, 20.IV 1984, 1 §, collector unknown (CZ).

DISTRIBUTION. Holarctic Region, Brazil, Venezuela, Australia (Háva, 2015).

REMARKS. Thylodrias contractus is known as a pest of collection of insects (Zhantiev, 1976). We also found the larva of this species in the dried harmala herb (Peganum harmala L., 1753) brought from Tajikistan, presumably the city of Khujand. In Kalmykia, it possibly lives in the natural environment. This assumption is supported by the observations of Zhantiev (1976) in the arid stations of Turkmenistan, which are in many respects similar to those in Kalmykia.

\section{Genus Thorictus Germar, 1834}

\section{Thorictus koenigi Reitter, 1887}

MATERIAL EXAMINED. Turkmenistan: Krasnovodskaya area [= Balkan Region], Chilmamedkum sands, Kichi-Yazy Well, 20,5 km., in nest of Catagliphus setipes, 3.VII 1984, 1へ̂, leg. E. Khachikov (CZ).

DISTRIBUTION. This species was described from Central Asia (Turkestan). Nowadays it is known from Kazakhstan, Uzbekistan and Kyrgyzstan (Zhantiev, 2011; Háva 2015). Here it is recorded from Turkmenistan for the first time.

\section{Genus Dermestes Linnaeus, 1758}

\section{Dermestes intermedius Kalík, 1951}

MATERIAL EXAMINED. Russia: Rostov region: Rostov-on-Don, 21.V 2014, 1ð̄, leg. E. Khachikov (CZ); Veshenskaya vill., 13.VI 2004, 10̄, leg. E. Khachikov (CZ); Sholokhovskii distr., Nizhne-Matveevskii vill., 27.VI 2004, 2 + , leg. E. Khachikov, A. Rudaikov \& S. Petrushchenko (CZ).

DISTRIBUTION. Central and South-East Europe including Italy, Ukraine, Russia (Rostov region, the Republic of Ingushetia, North Ossetia), Turkey (Khachikov, 2008; Háva, 2015).

REMARKS. Dermestes intermedius is a free-living species, believed to feed on dead insects. 


\section{Dermestes erichsoni Ganglbauer, 1904}

MATERIAL EXAMINED. Russia: Rostov region: Mankovo-Beresovka vill., ravine forest, plant litter, 10.X 1979, 1今, leg. E. Khachikov (CZ); Georgia: South Ossetia: Tskhinvali env., 13.VII 2013, 1ð, 2ㅇ, leg. Yu. Komarov (CZ).

DISTRIBUTION. Algeria, Morocco, Tunisia, Europe, Ukraine, Russia (Caucasus), Syria, Turkey, Georgia (Zhantiev, 1976; Pushkin, 2002; Háva, 2015). New record for Rostov region.

REMARKS. Dermestes erichsoni was collected by us in a litter of a ravine oak forest. According to Zhantiev (1976), the larvae of this species feed on the clutches of the gypsy moth Lymantria dispar (Linnaeus, 1758).

\section{CONCLUSION}

A list of the nine species in five genera of Dermestidae is given. Phradonoma beskalensis sp. $\mathrm{n}$. is described from Kazakhstan. Thorictus koenigi is recorded from Turkmenistan for the first time, Phradonoma villosulum is new for the fauna of Uzbekistan, Phradonoma nigrum is recorded for the first time from Iran, and two species, Attagenus cyphonoides and Dermestes erichsoni, are new for the Rostov region of Russia. Two species (Attagenus cyphonoides and Thylodrias contractus) should be considered as potential pests of collection materials and agricultural products in southern Russia, and therefore they need additional examination.

\section{ACKNOWLEDGMENTS}

The authors are grateful to D. Kasatkin (Rostov-on-Don, Russia) for photo of Phradonoma beskalensis, to Yu. Komarov (Vladikavkaz, Russia) for the material provided, and to Miloslav Rakovič (Dobríichovice, Czech Republic) for the revision of the English manuscript.

The study was supported for S.V. Poushkova by the state assignment of SSC RAS (No. AAAA-A19-119011190176-7 and for J. Háva by the Ministry of Agriculture of the Czech Republic, institutional support MZE-RO0118.

\section{REFERENCES}

Háva, J. 2006. Notes on the genus Phradonoma from the Middle East with description of nine new species (Coleoptera: Dermestidae: Megatominae). Genus, 17: 79-94.

Háva, J. 2015. World Catalogue of Insects. Volume 13. Dermestidae (Coleoptera). Brill, Leiden/Boston. xxvi $+419 \mathrm{pp}$

Peacock, E.R. 1993. Handbooks for the Identification of British Insects 5 (3). Adults and larvae of Hide, Larder and Carpet Beetles and their relatives (Coleoptera: Dermestidae) and of Derodontid Beetles (Coleoptera: Derodontidae). Royal Entomological Society of London, London. $144 \mathrm{pp}$.

Pushkin, S.V. 2002. Carrion beetles and skin beetles (Coleoptera: Silphidae, Dermestidae) of the Central Ciscaucasia (fauna, ecology, economic importance). Abstract of dissertation. Astrakhan, 26 pp. [In Russian] 
Pushkin, S.V. 2019. Necrobiontnye coleoptera (Insecta; Coleoptera) of the South of Russia. Direct-Media Publishing, Moscow/Berlin. 183 pp. [In Russian]

Khachikov, E.A. 2008. The addition to the fauna of insects National Sholokhov MuseumReserve. P. 119-122. In: Museum-reserve: ecology and culture. Materials of III theoretical and practical conference. FGUK, Veshenskaya, Russia. 200 pp. [In Russian]

Zhantiev, R.D. 1976. Carpet beetles (Dermestidae) of USSR. Moscow University Publ., Moscow. 180 pp. [In Russian]

Zhantiev, R.D. 2011. New and little known dermestid beetles of the genus Thorictus (Coleoptera, Dermestidae). Entomological Review, 91(8): 1005-1010. DOI: 10.1134/ S0013873811080069 